\title{
Land-Use and Land-Cover Changes in Dong Trieu District, Vietnam, during Past Two Decades and Their Driving Forces
}

\author{
Thi-Thu Vu ${ }^{1}$ and Yuan Shen ${ }^{1,2, *(1)}$ \\ 1 Department of Soil and Environmental Sciences, National Chung Hsing University, \\ Taichung City 402, Taiwan; d107039005@mail.nchu.edu.tw \\ 2 Innovation and Development Center of Sustainable Agriculture, National Chung Hsing University, \\ Taichung City 402, Taiwan \\ * Correspondence: yshen@nchu.edu.tw; Tel.: +886-4-22872619; Fax: +886-4-22862043
}

Citation: Vu, T.-T.; Shen, Y. Land-Use and Land-Cover Changes in Dong Trieu District, Vietnam, during Past Two Decades and Their Driving Forces. Land 2021, 10, 798. https:// doi.org/10.3390/land10080798

Academic Editor: de Kirsten Beurs

Received: 14 June 2021

Accepted: 27 July 2021

Published: 29 July 2021

Publisher's Note: MDPI stays neutral with regard to jurisdictional claims in published maps and institutional affiliations.

Copyright: (c) 2021 by the authors. Licensee MDPI, Basel, Switzerland. This article is an open access article distributed under the terms and conditions of the Creative Commons Attribution (CC BY) license (https:// creativecommons.org/licenses/by/ $4.0 /)$.

\begin{abstract}
Land-use and land-cover (LULC) change analyses are useful in understanding the changes in our living environments and their driving factors. Modeling changes of LULC in the future, together with the driving factors derived through analyzing the trends of past LULC changes, bring the opportunity to assess and orientate the current and future land-use policies. As the entryway of Quang Ninh province, Vietnam, Dong Trieu locale has experienced significant LULC changes during the past two decades. In this study, the spatial distribution of six Level I LULC classes, forest, cropland, orchards, waterbody, built-up, and barren land, in Dong Trieu district at 2000, 2010, and 2019 were obtained from Landsat imageries by maximum likelihood technique. The most significant changes observed over the past twenty years are a decrease of barren land (9.1\%) and increases of built-up (8.1\%) and orchards (6.8\%). Driving factor analysis indicated that the changes of cropland and built-up were dependent on distance from road (DFR), distance from main road (DFMR), distance from urban (DFU), distance from water (DFW), elevation, slope, and population density. The changes of forest were dependent on all the driving forces listed above, except DFMR. The orchards mainly appeared near the high-population-density area. The transformation of the waterbody was affected by geography (elevation and slope) and population density. The higher the population density, the less barren the land would appear.
\end{abstract}

Keywords: land use; land cover; Landsat; change detection; urbanization

\section{Introduction}

In $2018,55 \%$ of the total world populace lived in metropolitan areas. Projections show that urbanization, with the increasing trend of the total populace, could add another 2.5 billion individuals to metropolitan territories by 2050 , with nearly $90 \%$ of this increment occurring in Asia and Africa [1]. Forests, savannas, and steppes have already given way to agriculture to meet the demand for food and fiber of those metropolitan occupants [2]. The demand for food and fiber is expected to increase $68 \%$ by 2050 [1].

Change detection is an important application of remote sensing, by observing objects or phenomena at different times through earth-orbiting satellites $[3,4]$, to assess the status variations of the objects or phenomena [5]. It is commonly used to investigate the effects and consequences of human-made interactions on natural environments by comparing landuse and land-cover (LULC) maps of the same geographic region produced from archived satellite imageries. The Landsat archive, which is adequately consistent in imageries acquired from prior missions, permits us to evaluate long-term LULC changes, either local or worldwide [6]. Image classification categorizes pixels with a typical reflectance range into specific LULC classes [7-9]. Supervised classification is a method that involves selecting training sites as references to the classification results $[7,9,10]$. Parallelepiped, minimum distance, Mahalanobis distance, maximum likelihood, spectral angle mapper, 
and binary encoding are classification methods commonly used when implementing supervised classification [11].

Land use depends on the indigenous habitat and involvement of human activities. Hence, awareness of the driving components of the LULC is pivotal for land-use planning and administration [12]. However, the assessment of driving forces is subject to the comprehension of the cause-and-effect connection between the changes and their main driving forces, because the information on the causes enables the primary driving forces and classifications of phenomena that create the change to be grouped. For example, agriculture extension and degradation in the forest are typical land-use changes brought about by populace development that have expanded the interest for the land resources to guarantee food supply and improving life of quality [13]. Furthermore, agricultural development policies or forest protection and conservation policies have also been accounted as the driving forces of land-use change $[14,15]$. Moreover, profits from agriculture products have led to the conversion from the low-value land-use type to land-use types of higher values [16]. Studies on driving forces of natural and environmental changes, especially the conversion of cropland, forest, and barren land to urban uses, have recently emerged as the focus of sustainable land use management [17-19].

Dong Trieu district, Vietnam, experienced a radical LULC change due to population expansion, economic growth, and changes in the agriculture cultivation system over the past 20 years. However, the driving factors of LULC have not been studied. Therefore, the aims of this study were (1) to map and quantify the LULC changes in the Dong Trieu district during the last two decades (2000-2019), using multi-temporal remotely sensed satellite imagery, and (2) to evaluate the driving factors causing the changes.

\section{Methodology}

This study was divided into two parts, as shown in Figure 1. In the first part, LULC maps in 2000, 2010, and 2019 were produced from Landsat images by a supervised classification technique. In the second part of the study, driving factors that have caused the observed LULC changes between studied years were identified through Cramer's V Coefficients Evaluation.

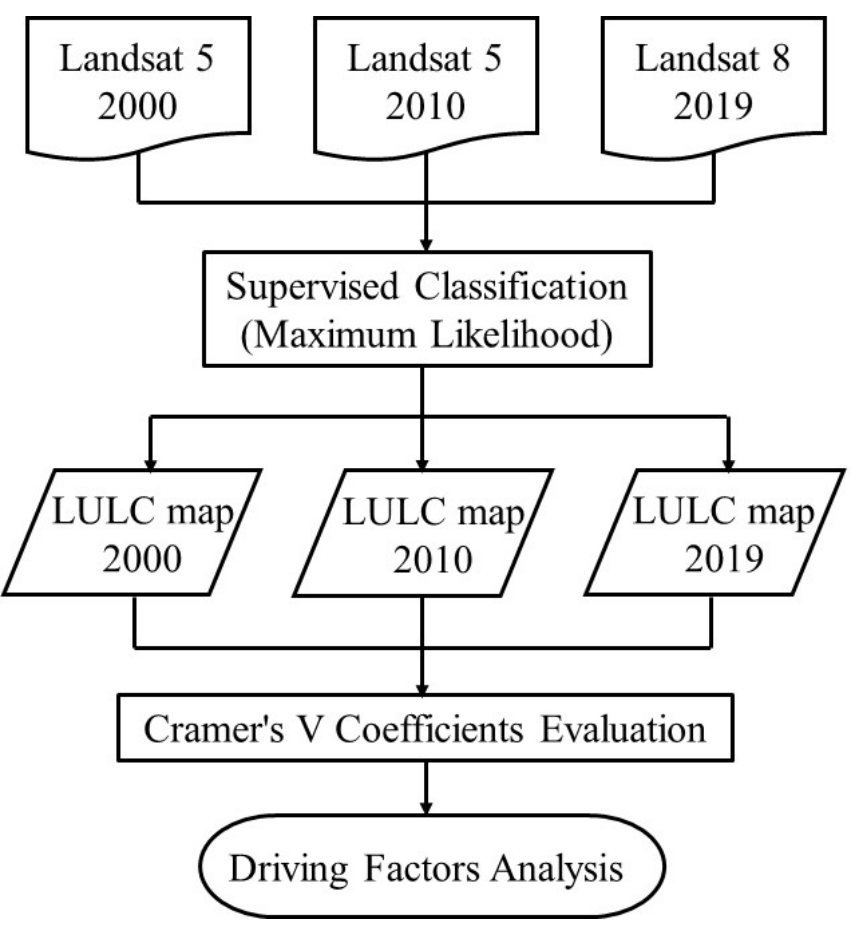

Figure 1. A flowchart for the methodologies used in this study. 


\subsection{Study Area}

Dong Trieu district, as the entryway of Quang Ninh province, is located in the northeast region of Vietnam, between $21^{\circ} 29^{\prime} 04^{\prime \prime}$ and $21^{\circ} 44^{\prime} 55^{\prime \prime}$ North latitude, and $106^{\circ} 33^{\prime}$ and $106^{\circ} 44^{\prime} 57^{\prime \prime}$ East longitude (Figure 2). Coal mining is the largest industry in the northeastern part of the district, with about 2.5 million tons of coal produced in 2019. Additionally, Dong Trieu has various resources, such as bricks, limestone, sand, and clay. According to collected data from the Yearly Statistics Book of Dong Trieu district from 2000 to 2019, the average population growth rate was $0.62 \%$ from 2000 to 2005 , and $1.54 \%$ from 2006 to 2019 [20]. The rapid increase of population since 2006 was due to the establishment of industrial zones and changes in economic structure. Although the cropland production in the GDP declined rapidly from $44.77 \%$ in 2000 to $10.6 \%$ in 2019 , its value increased from 300 to 468.72 billion VND in the studied 19 years [20].

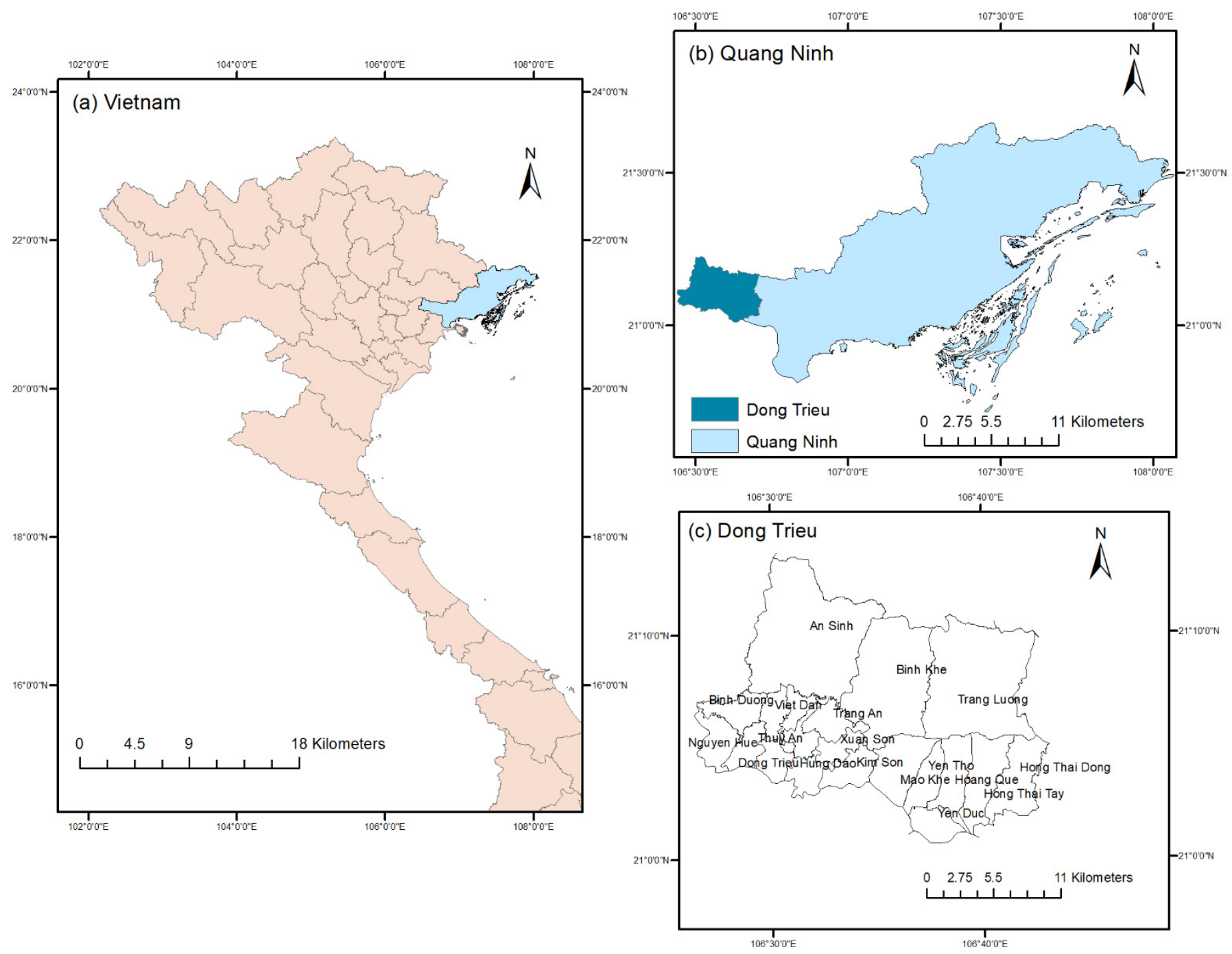

Figure 2. Location maps of the study area.

\subsection{Satellite Data}

To monitor the land-use and land-cover changes, cloud-free scenes of Landsat Thematic Mapper-TM $(2000,2010)$ and Operational Land Imager-OLI (2019) were utilized for analyzing LULC change in Dong Trieu (Table 1). The radiometric and atmospheric corrected images were downloaded from United States Geological Survey (USGS) (https: / / earthexplorer.usgs.gov/, accessed on 18 April 2020). These images were then processed and classified by using ENVI (Ver 5.1, Harris Geospatial Solutions, Broomfield, CO, USA). 
The change detection and map production were conducted by ArcGIS (Ver 10.5, ArcGIS, ESRI, Redlands, CA, USA).

Table 1. Characteristics of the satellite images used.

\begin{tabular}{ccccccc}
\hline Landsat & Sensor & Resolution $(\mathbf{m})$ & Range $(\boldsymbol{\mu m})$ & Bands & Path/Row & Date \\
\hline 5 & TM & 30 & $0.45-0.90$ & $1,2,3,4$ & $148-49 / 36-37$ & 23 November 2000 \\
5 & TM & 30 & $0.45-0.90$ & $1,2,3,4$ & $148-49 / 36-37$ & 27 December 2010 \\
8 & OLI & 30 & $0.452-0.879$ & $2,3,4,5$ & $148-49 / 36-37$ & 17 December 2019 \\
\hline
\end{tabular}

\subsection{Land Use/Land Cover Classification}

The maximum likelihood classifier was employed for LULC classification in this study. For 2000 and 2019, existing LULC maps, Google Earth imagery, and information collected from interviews with local experts were used to select specific training sites. The sample separability ranged from 1.8 to 2.0, measured by using the transformed divergence distance. Six LULC Level I classes, namely forest, cropland, orchard, waterbody, built-up, and barren land, were classified (Table 2).

Table 2. Descriptions of the LULC classes used in this study.

\begin{tabular}{cc}
\hline Class & Description \\
\hline Forest & Natural forest, planted forest \\
Cropland & Paddy rice, other annual crops (vegetable crops) \\
Orchard & Fruits, other perennial crops \\
Water & River, stream, lake, aquaculture land \\
Built-up & Residential land, industrial land, traffic land, construction areas \\
Barren land & Exposed rock, coal mines, raw material quarries \\
\hline
\end{tabular}

\subsection{Accuracy Assessment}

The classification accuracy of all three images (2000, 2010, and 2019) in the study was assessed by an error matrix using Google Earth and Land use maps from Dong Trieu Division of Natural Resources and Environment (DONRE). The true agreement from this validation is measured by the Kappa coefficient. The Kappa coefficient is broadly utilized in LULC accuracy assessment to compute the true agreement between the observed agreement and chance agreement [21]. A stratified random sampling technique was employed in the accuracy assessment to assure that smaller area classes would also have sampling points [22]. The overall accuracy and kappa coefficient were calculated by Equations (1) and (2).

$$
\text { Overall accuracy }=\frac{\sum_{i=1}^{r} x_{i i}}{x}
$$

where $x_{i i}$ is the diagonal components in the error matrix, and $x$ is the total samples in the error matrix. The kappa coefficient reflects the difference between actual agreement and the agreement expected by chance:

$$
\text { Kappa coefficient }(\hat{K})=\frac{n \sum_{i=1}^{r} x_{i i}-\sum_{i=1}^{r} x_{i}+x_{+1}}{n^{2}-\sum_{i=1}^{r} x_{i}+x_{+i}}
$$

where $r$ is the number of rows; $x_{i i}$ is the observations at row $i$ and column $i ; x_{i+}$ and $x_{+i}$ are the sum of row $i$ and column $i$, respectively; and $n$ is the number of observations.

\subsection{Driving Forces}

Driving forces are natural or socioeconomic phenomena causing land-use change. Limited by data availability, only seven spatial variables commonly used [14,23-27] were considered in this study, i.e., distance from road (DFR), distance from main road (DFMR), distance from urban (DFU), distance from water (DFW), elevation, slope, and population 
density (Table 3). The DFR, DFMR, DFU, and DFW were processed by using the Euclidean distance tool in ArcGIS. The slope and elevation were processed from the digital elevation model (DEM) in ArcGIS, with elevation divided into five classes, ranging from under $200 \mathrm{~m}$ to higher than $800 \mathrm{~m}$ (i.e., $<200 \mathrm{~m}, 200-400 \mathrm{~m}, 400-600 \mathrm{~m}, 600-800 \mathrm{~m}$, and higher than $800 \mathrm{~m}$ ), and slope divided into five classes from under $2^{\circ}$ to higher than $25^{\circ}$ (i.e., $<2^{\circ}$, $2-8^{\circ}, 8-15^{\circ}, 15-25^{\circ}$, and higher than $25^{\circ}$ ), in accordance with the general guidelines in delineating geographical categories at the district level in Vietnam [28,29]. The population density was classified into nine classes, from under 100 people $\mathrm{km}^{-2}$ to more than 5000 people $\mathrm{km}^{-2}$ (i.e., $<100$ people $\mathrm{km}^{-2}$, 100-250 people $\mathrm{km}^{-2}$, 251-500 people $\mathrm{km}^{-2}$, 501-100 people $\mathrm{km}^{-2}, 1001-2000$ people $\mathrm{km}^{-2}$, 2001-3000 people $\mathrm{km}^{-2}$, 3001-4000 people $\mathrm{km}^{-2}, 4001-5000$ people $\mathrm{km}^{-2}$, and more than 5000 people $\mathrm{km}^{-2}$ ) based on Vietnam population density classification scheme [30]. These seven factors were processed as grid maps with a cell size of $30 \mathrm{~m} \times 30 \mathrm{~m}$.

Table 3. Factors considered in driving force analysis for changes of LULC classes.

\begin{tabular}{cccc}
\hline No. & Data & Range & Classifying Method \\
\hline 1 & Distance from road $(\mathrm{m})$ & $0-3755.88$ & Euclidean Distance \\
2 & Distance from main road (m) & $0-11,810.6$ & Euclidean Distance \\
3 & Distance from urban $(\mathrm{m})$ & $0-15,391.9$ & Euclidean Distance \\
4 & Distance from water $(\mathrm{m})$ & $0-3945.09$ & Euclidean Distance \\
5 & Elevation $(\mathrm{m})$ & $50-850$ & Ranked \\
6 & Slope (\%) & $0-43^{\circ}$ & Ranked \\
7 & Population density (population $\left.\mathrm{km}^{-2}\right)$ & $37-5073$ & Ranked \\
\hline
\end{tabular}

\subsection{Cramer's V Coefficients Evaluation}

The correlations between the driving factors of LULC change were assessed by the Cramer's V Coefficient (CVC) or Cramer's V strategies [31]. The value of CVC was calculated by using Equation (3):

$$
V=\sqrt{\frac{\varphi}{\min (k-1, r-1)}}=\sqrt{\frac{\chi^{2} / n}{\min (k-1, r-1)}},
$$

where $\varphi$ is the coefficient of contingency, $\chi$ is derived from Pearson's chi-squared test, $n$ represents the total of observations, $k$ represents the number of columns, and $r$ represents the number of rows in the LULC images. The CVC has a value between 0 and 1 (inclusive). A value close to 1 demonstrates that a driving factor has a high possibility of being an explanatory variable. A high total CVC value (more than 0.15 ) represents that the expected illustrative worth of the variable is acceptable or helpful; a value under 0.15 can be dismissed [31,32].

\section{Results and Discussions}

\subsection{Classification Accuracy Assessments}

Accuracy assessments of the LULC classification in 2000, 2010, and 2019 are listed in Table 4 . The overall accuracies were between $85.5 \%$ and $88.6 \%$, and the Kappa values were in the range of 0.84 to 0.88 , respectively, which indicated that the classifications were acceptable [4].

Major causes that yielded incorrect classifications were as follows: (1) A cropland may be under a rotating system. It might be recognized as a barren land or waterbody when the land was left for recuperation. (2) A majority of the forests in the studied region were plantation forests. It might be recognized as orchards, cropland, or barren land when the planted trees were still at the initial growth stage. (3) The residential areas were often surrounded by orchards. This could lead to difficulty in distinguishing between built-up and orchards. (4) It was challenging to separate cropland and barren land accurately at certain locations, contingent upon the states of the crops and the season. 
Table 4. Accuracy statistics of LULC maps produced from satellite imageries.

\begin{tabular}{ccccccc}
\hline & \multicolumn{2}{c}{2000} & \multicolumn{2}{c}{$\mathbf{2 0 1 0}$} & \multicolumn{2}{c}{$\mathbf{2 0 1 9}$} \\
\hline Class & UA (\%) & PA (\%) & UA (\%) & PA (\%) & UA (\%) & PA (\%) \\
\hline Forest & 88.7 & 91.7 & 93.1 & 91.3 & 92.9 & 93.8 \\
Cropland & 83.3 & 88.2 & 84.1 & 90.2 & 84.1 & 75.5 \\
Orchards & 83.3 & 78.4 & 83.0 & 93.6 & 84.2 & 82.1 \\
Waterbody & 85.2 & 82.1 & 92.9 & 76.5 & 94.4 & 94.4 \\
Built-up & 84.9 & 93.8 & 82.4 & 95.4 & 81.8 & 91.8 \\
Barren land & 80.0 & 60.6 & 82.1 & 63.9 & 85.7 & 81.8 \\
Overall (\%) accuracy & 85.5 & & 87.2 & & 88.6 & \\
Kappa & 0.84 & & 0.86 & & 0.88 & \\
\hline
\end{tabular}

UA: user's accuracy. PA: producer's accuracy.

\subsection{Temporal Changes of LULC Classes}

The statistics for the six LULC classes and their spatial distribution in 2000, 2010, and 2019 are represented in Table 5 and Figure 3. The forest occupied the largest area among all six classes throughout the entire study period in the studied region. In 2000, $41.2 \%$ of the land was covered with forest, followed by cropland $(16.0 \%)$ and orchards $(12.4 \%)$. The built-up $(11.5 \%)$, barren land $(10.3 \%)$, and waterbody $(8.6 \%)$ accounted for the smaller proportion of the study area.

Table 5. Distribution LULC classes in Dong Trieu district from 2000 to 2019.

\begin{tabular}{ccccccc}
\hline \multirow{2}{*}{ Class } & \multicolumn{2}{c}{$\mathbf{2 0 0 0}$} & \multicolumn{2}{c}{$\mathbf{2 0 1 0}$} & \multicolumn{2}{c}{$\mathbf{2 0 1 9}$} \\
\cline { 2 - 7 } & ha & \% & ha & \% & ha & \% \\
\hline Forest & $16,206.8$ & 41.2 & $17,184.3$ & 43.7 & $15,849.6$ & 40.3 \\
Cropland & 6310.4 & 16.0 & 6463.5 & 16.4 & 5560.9 & 14.1 \\
Orchard & 4884.4 & 12.4 & 4765.1 & 12.1 & 7548.6 & 19.2 \\
Waterbody & 3398.2 & 8.6 & 3339.5 & 8.5 & 2250.5 & 5.7 \\
Built-up & 4510.3 & 11.5 & 5677.7 & 14.4 & 7677.1 & 19.5 \\
Barren land & 4050.4 & 10.3 & 1930.5 & 4.9 & 473.9 & 1.2 \\
\hline
\end{tabular}

In 2010, forest and cropland still took first and second place with an aerial coverage of $43.7 \%$ and $16.4 \%$, respectively, while built-up increased considerably and went up to the third place, with a $14.4 \%$ areal coverage. On the contrary, the area of barren land declined about $50 \%$ compared to the year 2000 .

In 2019, the areal coverage of built-up increased to $19.5 \%$ and took second place in the ranking. The orchards also expanded dramatically with an increase of about 2800 ha, which was about 1.6 times that of 2010, and took third place with an areal coverage of $19.2 \%$. However, the cropland, waterbody, and barren land decreased by $2.3 \%, 2.8 \%$, and $3.7 \%$, respectively, from that of 2010 .

Therefore, the Dong Trieu district experienced various changes in LULC classes during the past two decades. Among all the changes of LULC classes, the rapid expansion of built-up and orchards and the dramatic decrease of barren land were the most significant changes in the Dong Trieu district. 

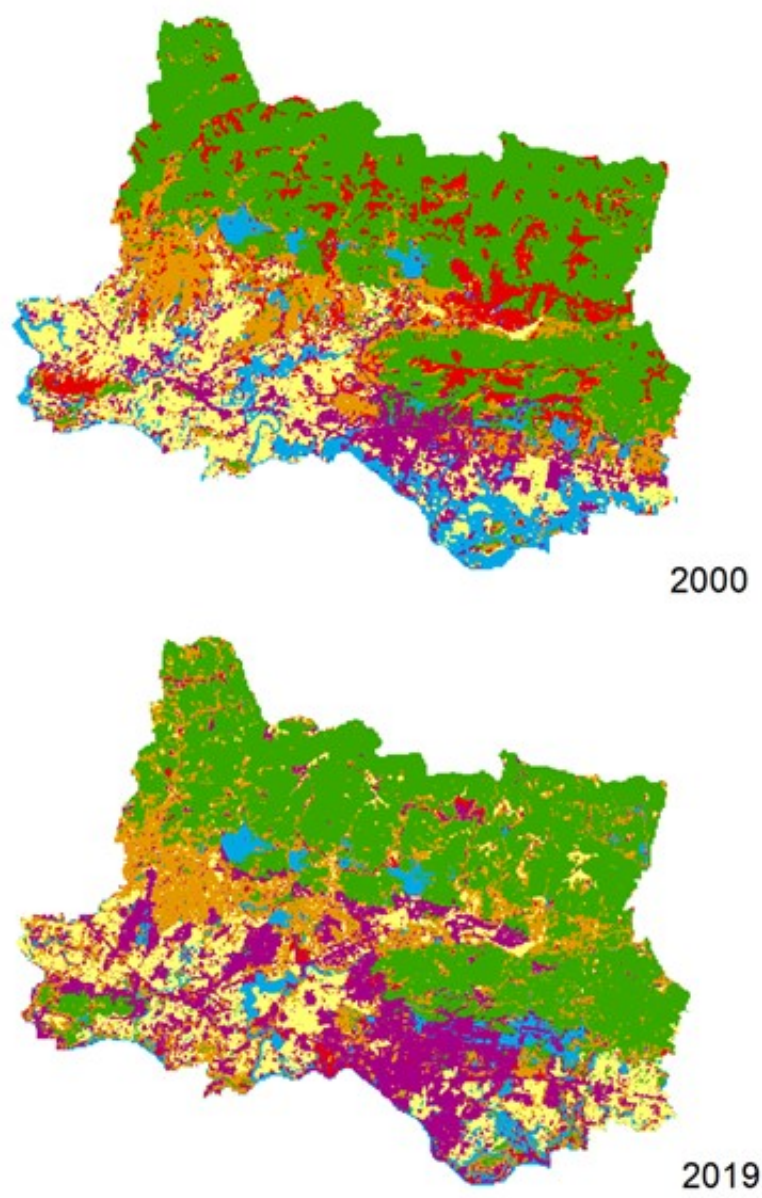
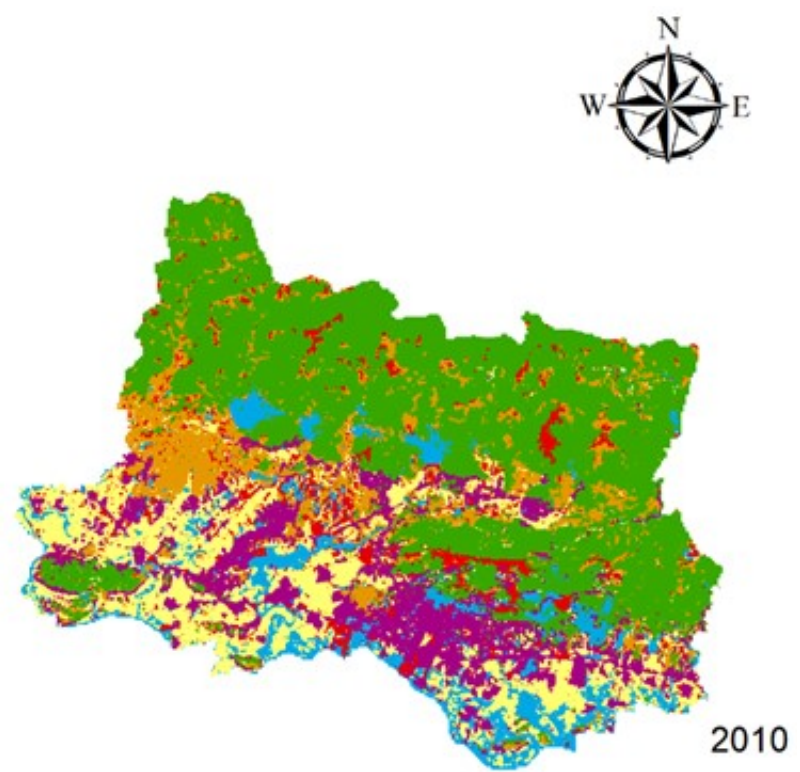

2010

Figure 3. Land-use/land-cover map of Dong Trieu district from 2000 to 2019.

\subsection{Conversions among LULC Classes}

Transformation matrices illustrating the conversions among LULC classes during the studied period are shown in Table 6. From 2000 to 2019, there were enormous changes in land-use practice from barren land (Table 6) and orchards (Table 7) to the forest in the Dong Trieu due to changes in forest plantation policy [33-35]. However, there was also a considerable conversion from forest to orchards (Table 7). A fair amount of forest was lost to built-up expansion in the entire study period (Table 8). The observed changes concur with the pattern seen by past investigations led in different parts in Northern Vietnam [36-38].

Table 6. The transformation matrices for changes of LULC classes from 2000 to 2010.

\begin{tabular}{cccccccc}
\hline \multicolumn{2}{c}{ Land Use $\mathbf{2 0 0 0}(\mathbf{h a})$} & \multicolumn{5}{c}{ Land Use $\mathbf{2 0 1 0}$ (ha) } \\
\hline Class & Area & Forest & Cropland & Orchards & Waterbody & Built-Up & Barren Land \\
\hline Forest & $16,206.8$ & $14,462.1$ & 167.5 & 755.1 & 185.3 & 343.9 & 292.9 \\
Cropland & 6310.4 & 127.6 & 3958.6 & 325.6 & 307.8 & 1205.8 & 385.1 \\
Orchards & 4884.4 & 962.7 & 358.8 & 2216.8 & 68.7 & 931.9 & 345.5 \\
Waterbody & 3398.2 & 83.3 & 721.1 & 28.4 & 2378.2 & 117.4 & 69.8 \\
Built-up & 4510.3 & 229.6 & 836.1 & 250.5 & 309.5 & 2731.9 & 152.8 \\
Barren land & 4050.4 & 1318.9 & 421.5 & 1188.7 & 90.0 & 346.8 & 684.5 \\
Total & $39,360.5$ & $17,184.2$ & 6463.5 & 4765.1 & 3339.5 & 5677.7 & 1930.5 \\
\hline
\end{tabular}


Table 7. The transformation matrices for changes of LULC classes from 2010 to 2019.

\begin{tabular}{cccccccc}
\hline \multicolumn{2}{c}{ Land Use $\mathbf{2 0 1 0}$ (ha) } & \multicolumn{5}{c}{ Land Use 2019 (ha) } \\
\hline Class & Area & Forest & Cropland & Orchards & Waterbody & Built-Up & Barren Land \\
\hline Forest & $17,184.3$ & $13,946.6$ & 269.1 & 2041.1 & 166.5 & 668.3 & 92.7 \\
Cropland & 6463.5 & 135.7 & 3266.4 & 1293.1 & 198.2 & 1509.0 & 61.2 \\
Orchards & 4765.1 & 1067.5 & 611.6 & 2412.4 & 25.3 & 561.9 & 86.3 \\
Waterbody & 3339.5 & 136.7 & 287.3 & 397.1 & 1721.7 & 761.8 & 34.9 \\
Built-up & 5677.7 & 194.7 & 701.0 & 948.8 & 81.1 & 57.7 & 488.4 \\
Barren land & 1930.5 & 368.4 & 425.5 & 456.2 & 57.6 & 134.4 \\
Total & $39,360.5$ & $15,849.5$ & 5560.9 & 7548.6 & 2250.5 & 7677.1 & 473.9 \\
\hline
\end{tabular}

Table 8. The transformation matrices for changes of LULC classes from 2000 to 2019.

\begin{tabular}{cccccccc}
\hline \multicolumn{2}{c}{ Land Use 2000 (ha) } & \multicolumn{5}{c}{ Land Use 2019 (ha) } \\
\hline Class & Area & Forest & Cropland & Orchards & Waterbody & Built-Up & Barren Land \\
\hline Forest & $16,206.8$ & $14,516.2$ & 264.4 & 2005.9 & 220.1 & 745.5 & 74.5 \\
Cropland & 6310.4 & 117.4 & 2895.6 & 1217.5 & 182.7 & 1794.6 & 102.6 \\
Orchards & 4884.4 & 928.0 & 499.4 & 2086.5 & 68.5 & 1204.0 & 97.9 \\
Waterbody & 3398.2 & 123.3 & 486.3 & 407.4 & 1534.0 & 796.8 & 50.5 \\
Built-up & 4510.3 & 164.6 & 745.8 & 783.8 & 156.7 & 68.0 & 545.1 \\
Barren land & 4050.4 & 1619.9 & 669.4 & 1047.6 & 88.5 & 70.0 \\
Total & $39,360.5$ & $15,849.6$ & 5560.9 & 7548.6 & 2250.5 & 767.1 & 473.9 \\
\hline
\end{tabular}

The area of cropland class experienced a slight increase (about $4 \%$ ) from 2000 to 2010 (Table 6) but a significant reduction of 14.1\% from 2010 to 2019 (Table 7). The main reason for this significant reduction is the change in land-use practice from paddy rice to fruit-planting orchards, and the expansion of built-up areas resulted from population increase and economic development. Similar developments were also observed in other places in Vietnam and China [38,39]. Conversions of croplands into aquaculture ponds mainly occurred in the southeast of the studied region, such as Yen Duc, Hoang Que, Hong Thai Dong, and Hong Thai Tay Communes. Similar conversions have also been identified in other places in Vietnam [40-43].

Orchards (e.g., dragon fruit, orange, and lychee) was the LULC class that developed most quickly and widely across the Dong Trieu district. From 2000 to 2010, a slight decrease in orchards area from $12.4 \%$ to $12.1 \%$ was found, but the area occupied by orchards increased nearly 7\% in 2000-2019 (Table 5). From 2010 to 2019, orchards spread quickly in the northwest of the studied region. The orchards gained most of their area from the forest, cropland, and barren land (Table 7). The conversion of cropland to orchards was unavoidable because of higher economic returns from orchards, especially from the custard apple plantation [44]. The conversion of croplands and barren land to orchards also occurred in other locations, such as Tien Yen districts, Northern Vietnam [38], Northern Thai Land [45], and Southern Thailand [46]. Additionally, the shortage of irrigation water due to water pollution in mining areas [47] gave farmers no choice but to change from cropland to orchards.

The areal percentage occupied by waterbody experienced a continuous decline of $8.6 \%, 8.5 \%$, and $5.7 \%$ in 2000, 2010, and 2019, respectively (Table 5). Nevertheless, the speed of decrease was most extreme from 2010 to 2019. Factors responsible for the decline in the waterbody are (1) the demand for food and settlements in the district, which caused the disappearance of some small ponds and made way for cropland, orchards, and built-up (Table 8); and (2) mining activities caused some waterbody to turn into barren land [48,49].

The areal percentages occupied by built-up in 2000, 2010, and 2019 were $11.5 \%$, $14.4 \%$, and $19.5 \%$, respectively, and experienced a total increase of 3166.8 ha from 2000 to 2019 (Table 5). The increase of built-up area mainly came from cropland and orchards, approximately 1800 ha and about 1200 ha, respectively (Table 8). Factors that contributed 
to the growth of GDP, such as the development of industries and services and increase of agricultural production (Table 9), have resulted in the expansion of residential and commercial areas and the extensions of new streets and trench networks that attributed to the noticeable increase in built-up areas. This extension in built-up areas was also associated with the $10 \%$ expansion in population, including residents and immigrant factory workers, during the past two decades [20]. It was estimated that, between 2001 and 2010, nearly one million hectares of agricultural land was compulsorily acquired by the government for non-agricultural uses [50], such as industrial zones, infrastructure, urban areas, and other public use purposes [51].

The areal percentage occupied by barren land also experienced a continuous decline of $10.3 \%, 4.9 \%$, and $1.2 \%$ in 2000, 2010, and 2019, respectively (Table 5). Most of the barren lands were converted to forest and orchards between 2000 and 2010, due to the orchards orientation policy and forest policy in this period (Table 6). Similar changes were also observed in other forest areas in Northern Vietnam [33,34,52].

Table 9. Changes of socioeconomic factors from 2000 to 2019 and correlations with the built-up area.

\begin{tabular}{ccccc}
\hline Socioeconomic Variables & $\mathbf{2 0 0 0}$ & $\mathbf{2 0 1 0}$ & $\mathbf{2 0 1 9}$ & Correlation \\
\hline GDP (million USD) & 19 & 174 & 309 & 0.989 \\
Per capital GDP (USD) & 234 & 1050 & 1760 & 0.988 \\
Industrial and Buildings (billion VND) & 290 & 1400 & 2438 & 0.991 \\
Commercial and Service (billion VND) & 80 & 420 & 4055 & 0.998 \\
Agriculture (billion VND) & 300 & 384 & 468.72 & 0.994 \\
\hline
\end{tabular}

\subsection{Driving Forces for LULC Changes}

The overall CVC values for each analyzed factor are listed in Table 10. This index describes the quantitative levels of associations of a driving factor with individual or all LULC classes. Although the overall Cramer's V Coefficient (CVC) of distance from road (DFR) was slightly less than 0.15 , the CVCs of DFR for forest, built-up land, and cropland were higher than 0.15 . Therefore, the DFR was one of the factors that affected the changes in forest, built-up, and cropland. The distance from main road (DFMR) is the main driving factor that contributed to the large area conversion of cropland to built-up, as shown in Table 6.

Table 10. Cramer's correlation analysis of the seven driving factors selected.

\begin{tabular}{cccccccc}
\hline Driving Factors & Overall CVC & Forest & Cropland & Orchards & Waterbody & Built-Up & Barren Land \\
\hline Distance from road & 0.148 & 0.266 & 0.151 & 0.034 & 0.122 & 0.203 & 0.031 \\
Distance from main road & 0.272 & 0.054 & 0.311 & 0.081 & 0.137 & 0.351 & 0.052 \\
Distance from urban & 0.299 & 0.560 & 0.311 & 0.166 & 0.174 & 0.392 & 0.070 \\
Distance from water & 0.202 & 0.388 & 0.216 & 0.066 & 0.230 & 0.167 & 0.061 \\
Elevation & 0.225 & 0.413 & 0.230 & 0.052 & 0.155 & 0.204 & 0.054 \\
Slope & 0.319 & 0.608 & 0.326 & 0.099 & 0.207 & 0.266 & 0.020 \\
Population density & 0.352 & 0.556 & 0.447 & 0.213 & 0.328 & 0.384 & 0.117 \\
\hline
\end{tabular}

The CVCs of the distance from urban (DFU) for forest, built-up, and cropland are $0.560,0.392$, and 0.311, respectively. Therefore, the deforestation in Dong Trieu district was mainly attributed to the agricultural land spread into the forest, urban expansion, and increased demand for raw materials for paper production and furniture associated with the economic growth. This phenomenon was also observed in other parts of Vietnam [53].

The CVCs of distance from water (DFW) for forest, waterbody, and cropland are 0.388 , 0.230 , and 0.216 , respectively, which suggested that the water area in this study was often located far from the forest. The cropland, however, often occurred near the water areas, possibly due to easy water accessibility. The continuous decline of the waterbody area caused the conversion of cropland to orchards or forests, as shown in Table 6 to Table 8 , 
due to irrigation water shortage. This phenomenon has also been observed in other Asian regions [54-56].

The CVCs of elevation showed a relatively strong relationship with forest (0.413), which indicated that the elevation has a good association with forest expansion. The distributions of built-up and cropland were less strongly affected by elevation, as indicated by their CVC values of 0.230 and 0.204 , respectively.

The CVCs of slope for forest, cropland, and built-up were $0.608,0.326$, and 0.266 , respectively. Thus, slope appeared to be a good predictor of forest, cropland, and builtup. It is noted that the studied region has quite a large variation in topography and socioeconomic complexity, so that elevation and slope have large overall CVCs. Similar correlations between forest expansion and topographic factors have been observed in Northwestern Vietnam [57].

The population density had the highest overall CVC value among all analyzed factors and high CVC values for forest, cropland, and built-up, at 0.556, 0.447, and 0.384, respectively. Not surprisingly, deforestation is more substantial at places closer to an existing area of higher population density. Furthermore, the locations closer to a high population density area have higher probabilities of conversion to built-up. These results showed that population pressure played an important role in increasing built-up area and conversion of forest to other land-use classes.

\section{Conclusions}

The spatial distribution of LULC classes identified through Landsat imageries acquired in 2000, 2010, and 2019 revealed significant LULC changes in the Dong Trieu district during the past two decades. The area under barren land, waterbody, cropland, and forest revealed a declining trend from 2000 to 2019, with a net decrease of 3576.5, 1147.7, 749.5, and 357.2 ha, respectively. The area under built-up and orchards exhibited an overall growing trend during the same period, with a net increase of 3166.8 and 2644.2 ha, respectively. The expansion and built-up area and the decrease of cropland were driven by all seven factors analyzed, i.e., distance from road (DFR), distance from main road (DFMR), distance from urban (DFU), distance from water (DFW), elevation, slope, and population density. The changes of forest were dependent on all the driving forces listed above, except DFMR. Orchards were established close to urban or areas of high population density. The transformation of the waterbody was affected by geography (elevation and slope) and population density. The higher the population density, the less the barren land would appear.

According to the roles of active driving factors depicted by this study, land-use planners and decision-makers of the Dong Trieu district should introduce more environmentfriendly livelihood and measures, such as population-growth control to reduce the pressure on demanding more build-up area and conversion of forest to other land-use classes; better water-resources managements to reduce irrigation water shortage problems; encouragement of intensive use of agricultural lands and high-tech farming to increase yields and decrease the demand on more croplands; and encouragement of community participation in forest management to protect and expand the forest area, with intentions to promote sustainable development in the future.

The methodologies presented in this study show how to combine satellite data with other ancillary data (DEM and population density in this study) that are varying in format, accuracy, and spatial resolution than remotely sensed images to understand the actual driving factors for structural changes of LULC in a given area. This can be a powerful planning tool with many positive insights into the policy and governance of a specific territory. A simulation study based on the roles of the driving factors depicted is currently being undertaken to further examine the potential impacts of these variables on land-use changes in future scenarios. 
Author Contributions: Conceptualization, Y.S.; data curation, T.-T.V.; formal analysis, T.-T.V.; investigation, T.-T.V.; supervision, Y.S.; visualization, T.-T.V.; writing—original draft, T.-T.V.; writing一review and editing, Y.S. Both authors have read and agreed to the published version of the manuscript.

Funding: This research received no external funding.

Acknowledgments: We gratefully acknowledge the Ministry of Science and Technology, Taiwan, for the scholarship support to the first author for her Ph.D. study in Taiwan. We also thank the support of Dong Trieu Division of Natural Resources and Environment, Vietnam, for providing the auxiliary data.

Conflicts of Interest: The authors declare no conflict of interest.

\section{References}

1. Ritchie, H.; Roser, M. Urbanization. Available online: https:/ / ourworldindata.org/urbanization (accessed on 11 June 2020).

2. Lambin, E.F.; Geist, H.J.; Lepers, E. Dynamics of land-use and land-cover change in tropical regions. Annu. Rev. Environ. Resour. 2003, 28, 205-241. [CrossRef]

3. Nelson, R.F. Detecting forest canopy change due to insect activity using Landsat MSS. Photogramm. Eng. Remote Sens. 1983, 49, 1303-1314.

4. Anderson, J.R. A Land Use and Land Cover Classification System for Use with Remote Sensor Data; US Government Printing Office: Washington, DC, USA, 1976; Volume 964.

5. Singh, A. Review article digital change detection techniques using remotely-sensed data. Int. J. Remote Sens. 1989, 10, 989-1003. [CrossRef]

6. Irons, J.R.; Dwyer, J.L.; Barsi, J.A. The next Landsat satellite: The Landsat data continuity mission. Remote Sens. Environ. 2012, 122, 11-21. [CrossRef]

7. Lillesand, T.M.; Kiefer, R.W. Remote Sensing and Photo Interpretation; John Wiley and Sons: New York, NY, USA, 1994.

8. Chica-Olmo, M.; Abarca-Hernandez, F. Computing geostatistical image texture for remotely sensed data classification. Comput. Geosci. 2000, 26, 373-383. [CrossRef]

9. Egorov, A.V.; Hansen, M.C.; Roy, D.P.; Kommareddy, A.; Potapov, P.V. Image interpretation-guided supervised classification using nested segmentation. Remote Sens. Environ. 2015, 165, 135-147. [CrossRef]

10. Chen, D.M.; Stow, D. The effect of training strategies on supervised classification at different spatial resolutions. Photogramm. Eng. Remote Sens. 2002, 68, 1155-1161.

11. Rajalakshmi, K.; Murugan, D.; Manish, T.I. Supervised Methods for Land Use Classification. IJRIT Int. J. Res. Inf. Technol. 2013, 1, 64-73.

12. Briassoulis, H. Analysis of Land Use Change: Theoretical and Modeling Approaches; Loveridge, S., Jackson, R., Eds.; West Virginia University, WVU Research Repository: Lesvos, Greece, 2019.

13. Meyer, W.B.; Turner, B.L. Human population growth and global land-use/cover change. Annu. Rev. Ecol. Syst. 1992, $23,39-61$. [CrossRef]

14. Msofe, N.K.; Sheng, L.X.; Lyimo, J. Land Use Change Trends and Their Driving Forces in the Kilombero Valley Floodplain, Southeastern Tanzania. Sustainability 2019, 11, 505. [CrossRef]

15. Garrett, R.D.; Koh, I.; Lambin, E.F.; de Waroux, Y.L.; Kastens, J.H.; Brown, J.C. Intensification in agriculture-forest frontiers: Land use responses to development and conservation policies in Brazil. Glob. Environ. Chang 2018, 53, 233-243. [CrossRef]

16. Fao, F. The Future of Food and Agriculture-Trends and Challenges; FAO: Rome, Italy, 2017; p. 180.

17. Turner, B.L.; Lambin, E.F.; Reenberg, A. The emergence of land change science for global environmental change and sustainability. Proc. Natl. Acad. Sci. 2007, 104, 20666-20671. [CrossRef] [PubMed]

18. Kotaridis, I.; Lazaridou, M. Environmental Change Detection Study in the Wider Area of Lignite Mines. Civ. Eng. Archit. 2018, 6, 108-114. [CrossRef]

19. Othman, A.A.; Al-Saady, Y.I.; Al-Khafaji, A.K.; Gloaguen, R. Environmental change detection in the central part of Iraq using remote sensing data and GIS. Arab. J. Geosci. 2014, 7, 1017-1028. [CrossRef]

20. Dong Trieu Statistics Department Statistical Yearbook 2010-2019; Dong Trieu Statistic Publisher: Dong Trieu, Vietnam, 2019.

21. Rwanga, S.S.; Ndambuki, J.M. Accuracy assessment of land use/land cover classification using remote sensing and GIS. Int. J. Geosci. 2017, 8, 611. [CrossRef]

22. Padilla, M.; Stehman, S.V.; Ramo, R.; Corti, D.; Hantson, S.; Oliva, P.; Alonso-Canas, I.; Bradley, A.V.; Tansey, K.; Mota, B. Comparing the accuracies of remote sensing global burned area products using stratified random sampling and estimation. Remote Sens. Environ. 2015, 160, 114-121. [CrossRef]

23. Nguyen, H.H.; Dargusch, P.; Moss, P.; Aziz, A.A. Land-use change and socio-ecological drivers of wetland conversion in Ha Tien Plain, Mekong Delta, Vietnam. Land Use Policy 2017, 64, 101-113. [CrossRef]

24. Minallah, M.; Ghaffar, A.; Rafique, M.; Mohsin, M. Urban growth and socio-economic development in Gujranwala, Pakistan: A geographical analysis. Pak. J. Sci. 2016, 68, 176. 
25. Masud, S.; Ali, Z.; Haq, M.; Ghuri, B.M. Monitoring and predicting landuse/landcover change using an integrated markov chain \& multilayer perceptron models: A case study of sahiwal tehsil. J. GeoSpace Sci. 2016, 1, 43-59.

26. Ayele, G.; Hayicho, H.; Alemu, M. Land Use Land Cover Change Detection and Deforestation Modeling: In Delomena District of Bale Zone, Ethiopia. J. Environ. Prot. 2019, 10, 532-561. [CrossRef]

27. Zhao, X.; Pu, J.; Wang, X.; Chen, J.; Yang, L.E.; Gu, Z. Land-use spatio-Temporal change and its driving factors in an artificial forest area in Southwest China. Sustainability 2018, 10, 4066. [CrossRef]

28. Huong, N.H.N.; Tran, T. Land Survey Handbook; Forestry University Publisher: Hanoi, Vietnam, 2018.

29. Chieu, T.T.B.; Le Thai, T.; Nguyen, V. (Eds.) Manual Survey, Classification and Land Evaluation; Agricultural Publisher: Hanoi, Vietnam, 1999.

30. Assembly, S.C.N. Goverment Resolution No 1210/2016/UBTVQH13 about Urban Classification; Standing Committee of the National Assembly: Hanoi, Vietnam, 2016.

31. Cramer, H. Mathematical Methods of Statistics; CramérMathematical Methods Stat; Princeton University Press: Princeton, NJ, USA, 1946.

32. Cohen, J. Statistical Power Analysis for the Behavioral Sciences; Academic Press: Cambridge, MA, USA, 2013.

33. Quang, N.V.; Noriko, S. Forest allocation policy and level of forest dependency of economic household groups: A case study in northern central Vietnam. Small-Scale For. 2008, 7, 49-66. [CrossRef]

34. Sunderlin, W.D. Poverty alleviation through community forestry in Cambodia, Laos, and Vietnam: An assessment of the potential. For. Policy Econ. 2006, 8, 386-396. [CrossRef]

35. Sikor, T. The allocation of forestry land in Vietnam: Did it cause the expansion of forests in the northwest? For. Policy Econ. 2001, 2,1-11. [CrossRef]

36. Nguyen, Q.-K. Landslide Hazard Assessment in Muong Lay, Vietnam, Applying GIS and Remote Sensing. Ph.D. Thesis, Greifswald University, Greifswald, Germany, 2010.

37. Phuong, T.H.; Hung, N.T. Analysing the land use change by using Landsat images—case in Daclak from 2000 to 2010. Tap Chí Khoa Hoc 2013, 112. [CrossRef]

38. Hien, N.T.T.; Thanh, P.V.; Thoi, N.K. Land use/land cover evaluation in Tien Yen District, Quang Ninh Province 2000-2010; Sci. Dev. J. Vietnam National University of Agriculture Publisher: Hanoi, Vietnam, 2014; p. 43.

39. Xiao, J.; Shen, Y.; Ge, J.; Tateishi, R.; Tang, C.; Liang, Y.; Huang, Z. Evaluating urban expansion and land use change in Shijiazhuang, China, by using GIS and remote sensing. Landsc. Urban Plan. 2006, 75, 69-80. [CrossRef]

40. Tang, J.; Li, Y.; Cui, S.; Xu, L.; Ding, S.; Nie, W. Linking land-use change, landscape patterns, and ecosystem services in a coastal watershed of southeastern China. Glob. Ecol. Conserv. 2020, 23, e01177. [CrossRef]

41. Nguyen, H.; Bui, X.-N.; Bui, H.-B.; Mai, N.-L. A comparative study of artificial neural networks in predicting blast-induced air-blast overpressure at Deo Nai open-pit coal mine, Vietnam. Neural Comput. Appl. 2020, 32, 3939-3955. [CrossRef]

42. Kruse, J.; Koch, M.; Khoi, C.M.; Braun, G.; Sebesvari, Z.; Amelung, W. Land use change from permanent rice to alternating rice-shrimp or permanent shrimp in the coastal Mekong Delta, Vietnam: Changes in the nutrient status and binding forms. Sci. Total Environ. 2020, 703, 134758. [CrossRef] [PubMed]

43. Ha, T.V.; Tuohy, M.; Irwin, M.; Tuan, P.V. Monitoring and mapping rural urbanization and land use changes using Landsat data in the northeast subtropical region of Vietnam. Egypt. J. Remote Sens. Space Sci. 2020, 23, 11-19. [CrossRef]

44. Vuong, Q.H. Vietnam's Political Economy in Transition (1986-2016). Stratfor-The Hub: International Perspectives. Texas, USA. 27 May 2014. Available online: https://worldview.stratfor.com/article/vietnams-political-economy-transition-1986-2016 (accessed on 14 June 2021).

45. Arunyawat, S.; Shrestha, R.P. Simulating future land use and ecosystem services in Northern Thailand. J. Land Use Sci. 2018, 13, 146-165. [CrossRef]

46. Wunbua, J.; Nakhapakorn, K.; Jirakajohnkool, S. Change detection and identification of land potential for planting Krajood (Lepironia articulata) in Thale Noi, Southern Thailand. Songklanakarin J. Sci. Technol. 2012, 34, 329-336.

47. Mien, T. Technical and Economic Aspects of Recent Achievements in Mine Water Management in the Mines of Quang Ninh Coal Basin, Vietnam. In Proceedings of the 13th International Mine Water Association Congress, Lappeenranta, Finland, 25-30 June 2017; p. 1348.

48. Broemme, K.; Stolpe, H.; Jolk, C.; Greassidis, S.; Borgmann, A.; Zindler, B. Development of a Methodology for Postmining Land Use Planning in Quang Ninh, Vietnam. In Proceedings of the Hanoi University of Mining and Geology, Third International Conference on Advances in Mining and Tunneling, Vung Tau, Vietnam, 21-22 October 2014; pp. 21-22.

49. Stiels, C.; Brömme, K.; Stolpe, H. GIS-Application for Environmental Management in Mining Areas on the Example of the Quang Ninh province, Vietnam. In Proceedings of the International Symposium on Geoinformatics for Spatial Infrastructure Development in Earth and Allied Sciences, Hanoi, Vietnam, 9-11 December 2010.

50. Bank, W. Compulsory Land Acquisition and Voluntary Land Conversion in Vietnam: The Conceptual Approach, Land Valuation and Grievance Redress Mechanisms; World Bank: Hanoi, Vietnam, 2011. 
51. Van Suu, N. Industrialization and Urbanization in Vietnam: How Appropriation of Agricultural Land Use Rights Transformed Farmers' Livelihoods in a Peri-Urban Hanoi Village? Final Report of an EADN Individual Research Grant Project. 2009. Available online: https://www.academia.edu/14477551/Industrialization_and_urbanization_in_Vietnam_How_appropriation_ of_agricultural_land_use_rights_transformer_farmers_livelihoods_in_a_per_urban_Hanoi_village?auto=download (accessed on 14 June 2021).

52. Sandewall, M.; Ohlsson, B.; Sandewall, R.K.; Viet, L.S. The expansion of farm-based plantation forestry in Vietnam. Ambio 2010, 39, 567-579. [CrossRef] [PubMed]

53. Van Khuc, Q.; Tran, B.Q.; Meyfroidt, P.; Paschke, M.W. Drivers of deforestation and forest degradation in Vietnam: An exploratory analysis at the national level. For. Policy Econ. 2018, 90, 128-141. [CrossRef]

54. Zhang, L.; Lu, D.; Li, Q.; Lu, S. Impacts of socioeconomic factors on cropland transition and its adaptation in Beijing, China. Environ. Earth Sci. 2018, 77, 1-10. [CrossRef]

55. Magesh, N.; Chandrasekar, N. Driving forces behind land transformations in the Tamiraparani sub-basin, South India. Remote Sens. Appl. Soc. Environ. 2017, 8, 12-19. [CrossRef]

56. Amuti, T.; Luo, G. Analysis of land cover change and its driving forces in a desert oasis landscape of Xinjiang, northwest China. Solid Earth 2014, 5, 1071-1085. [CrossRef]

57. Jadin, I.; Vanacker, V.; Hoang, H.T.T. Drivers of forest cover dynamics in smallholder farming systems: The case of Northwestern Vietnam. Ambio 2013, 42, 344-356. [CrossRef] 